\title{
10. UPPER TRIASSIC (RHAETIAN) SEQUENCES OF THE AUSTRALIAN NORTHWEST SHELF RECOVERED ON LEG 122: SEA-LEVEL CHANGES, TETHYAN RIFTING, AND OVERPRINT OF INDO-AUSTRALIAN BREAKUP1
}

\author{
Thierry Dumont ${ }^{2}$
}

\begin{abstract}
During Leg 122, Upper Triassic shallow-marine sequences capped by an erosional post-rift unconformity with a 80-m.y. sedimentary gap were recovered in the northern part of the Exmouth marginal plateau (Sites 759-761 and 764). The continent/ocean boundary is located only a few kilometers north of the northernmost site (Hole 764B). The components and microfacies of the most recent sediments below the post-rift unconformity (Rhaetian; about 200 samples) were analyzed. These sediments were found in two sites about $20 \mathrm{~km}$ apart (Holes 761C and 764B). Based on microfacies analysis and chemical logs, a correlation between these two sites is proposed. It is suggested that the uppermost Rhaetian beds at Site 764 do not exist at Site 761 (later erosion), and that the part existing in both holes (about $170 \mathrm{~m}$ ) is only $5 \%$ thicker at Site 764 . Rhaetian tilting along a north-south direction was thus insignificant $\left(0.02^{\circ}\right)$. The Rhaetian series are composed of two shallowing-upward sequences which correspond to third-order depositional sequences (sensu Haq et al., 1987). The lack of evidence for Rhaetian syn-sedimentary tectonics in the study area, and the similarities between the northwestern Australian sedimentary sequences and the European series, indicate that global eustasy has played a major role during the Rhaetian. The analysis of Rhaetian beds, which were deposited upon a rather stable platform, and the geometry of underlying Triassic beds, do not document any causal link between the Late Triassic rifting and the breakup in the nearby Argo Abyssal Plain 80 m.y. later. This breakup is probably more related to the Neocomian separation between India and Australia, and cuts obliquely through the rim of marginal plateaus of the older Tethyan margin. The geodynamic evolution of this latter Gondwanan Tethyan margin around the Triassic-Jurassic boundary appears closely comparable to, and synchronous with, the evolution of the European margin of the Ligurian Tethys, presently outcropping in the Western Alpine nappes.
\end{abstract}

\section{INTRODUCTION}

The Northwest Shelf off Australia is an old Gondwanan passive margin whose sedimentary sequences recorded the successive breakups of several Gondwanan continental blocks throughout the Mesozoic. Four sites (759, 760, 761, and 764) were drilled during Ocean Drilling Program (ODP) Leg 122 in the Wombat Plateau area, on the northern promontory of the Exmouth marginal plateau (von Rad et al., 1989a; Fig. 1A). The marginal plateaus offshore northwestern Australia bear a thin post-rift sedimentary cover of late Mesozoic to Holocene age, overlying a prominent, often erosional "post-rift unconformity" (PRU) (Barber, 1988; von Rad et al., 1989b). Thus, we were able to drill the pre-rift and syn-rift series, on which this chapter focuses. The four sites are distributed along a roughly north-south seismic profile (Fig. 1B). We recovered only Upper Triassic beds overlain by the PRU, which corresponds to a huge depositional (and erosional) gap of at least 80 m.y. As shown by the profile, erosion and angular unconformity increase toward the south, and therefore younger beds were drilled in the northern well. This paper focuses on these most recent pre-breakup beds (Rhaetian) for two reasons:

1. These beds were recovered at two Sites (761 and 764) about $20 \mathrm{~km}$ apart, and the abundance and the variety of open marine and platform carbonate facies provide data for a tentative correlation and an analysis of spatial and vertical facies development.

\footnotetext{
1 von Rad, U., Haq, B. U., et al., 1992. Proc. ODP, Sci. Results, 122: College Station, TX (Ocean Drilling Program).

2 Institut Dolomieu, Université Joseph Fourier, 15 rue Maurice Gignoux, 38031 Grenoble, France.
}

2. These beds are the most likely to have recorded some information about the anomalous behavior of the Wombat Plateau before the first oceanic crust appeared in Argo Abyssal Plain, because all the expected Jurassic sequence is missing.

In addition to the sedimentological and sequence history, which is detailed in the first sections, this chapter is concerned with the factors that played a major role during the deposition of Upper Triassic sequences. Indeed, the Triassic-Jurassic boundary is known all over the world as a sensitive time interval in terms of both plate tectonics and eustasy.

\section{UPPER TRIASSIC SEDIMENTS IN THE WOMBAT PLATEAU AREA}

Detailed descriptions of lithofacies of the material drilled during Leg 122 and of some other dredged rocks from the Wombat Plateau are given by von Rad et al. (in press) and by Shipboard Scientific Party (1990). The Upper Triassic lithofacies vary from fine-grained terrigenous siliciclastic sedimentation (prodelta to flood-plain environments), which is prevalent during the Carnian-Norian, to neritic carbonates culminating with the Rhaetian reefal limestones. A simplified description of Rhaetian lithofacies and their stratigraphy is given in Figure 1C (see Shipboard Scientific Party, 1990, for detailed data).

Siliciclastic facies of deltaic origin are dominant in Carnian and Norian series (Ito et al., this volume). They are deposited in an overall regressive cycle, punctuated by the episodic development of shallow carbonate wedges. Siliciclastic facies of the Rhaetian series are different: they occur in gray marine marls or marl/limestone alternations (lithofacies A, Fig. 1C), and are observed in the lower part of the Rhaetian sequence, 

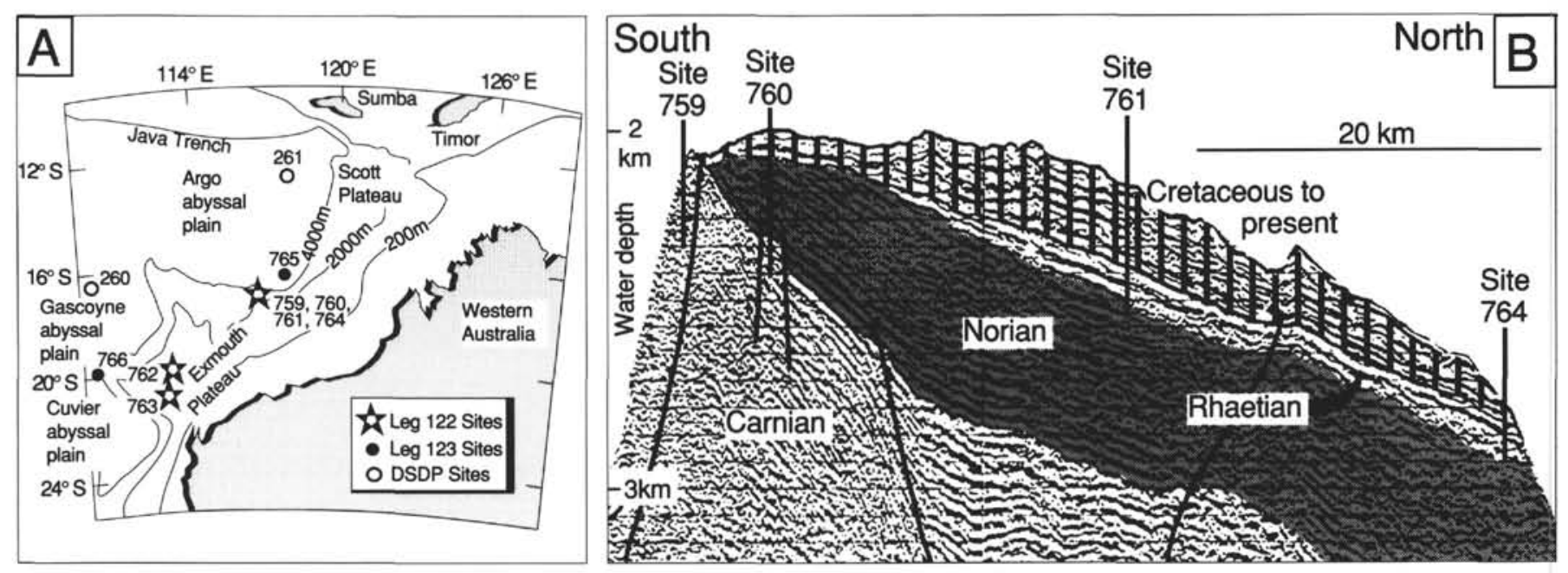

(a) gray marls or marl/limestone alternations, with evidences of outer shelf, below wave base, environments.

(b) Gray carbonate-cemented sandstones and quartz grainstone/packstone, which occur only at the very base of site 761 (core 761C-32R), just above the Norian-Rhaetian sequence boundary. Quartz grains are sorted, angular. Crinoids and other bioclasts are common. One intraclast is noticed, made up of ooid grainstone whose ooid cores are mainly quartz grains. (C) Gray carbonate mudstones and wackestones with various amount of clay. Bioturbation is common, bioclasts are mainly echinoids and sponge spicules (outer shelf, below wave base). d. Gray to brown crinoid-rich packstones and grainstones, with marine phreatic cements and components showing the proximity of carbonate banks or patch reefs (shallow outer shelf). (e). Light yellowish-reddish sponge boundstone, associated with red clay, brachiopods and minor corals. This is a special marker bed occurring in the lower part of both holes $761 \mathrm{C}$ and $764 \mathrm{~B}$, which underlies the development of patch reefs. (f) Whithish coral or coral-sponge boundstone and associated detrital wedges (patch reefs), with common moldic and intergranular porosity and geopetal fillings. Branching corals are frequently found in life position (site 764).

g) White lagoonal wackestones and packstones with foraminifera and thickshelled molluscs (Megalodon). Occasional keystone wugs, extensive secondary porosity and fresh water cements are noticed. Patchy dolomitization may occur. (h. Yellowish-white beach carbonate sands, containing well sorted ooids or rounded grains, frequently (cross)laminated. They are interbedded with algal laminations with bird's eyes, indicative of episodic tidal-flat development. Meteoricphreatic cements, secondary porosity and dolomitization are frequent.

(i) Brown, iron-oxide rich, carbonate packstones and wackestones with mixed crinoid and foraminifera faunas, showing evidences of condensation with iron-oxide concentration along dissolution surfaces. This facies, which is found at the very top of the Rhaetian sequence at site 764 , can be compared to some quartz-rich dredged material described by von Rad et al. (in press) which is possibly of Earliest Jurassic age (Quilty, in press) and has not been encountered by leg 122 due to Jurassic erosion of the Wombat Plateau.

(i) Originally a gray carbonate mudstone or wackestone with crinoids and/or sponge spicules, similar as lithofacies $\mathrm{g}$ ), but which is extensively recristallised. The recristallisation develops behind a sharp, highly contorted ferruginous front (bacterial activity ?) which obliterates the original sedimentary structures and bioclasts. This phenomenon postdates induration and even fracturing of the original sediment. The elongated shape of the calcite crystals and their organization (sometimes radial or parallel) could evoque a pedogenetic alteration. (k)-Regular, subparallel iron-oxide banding superimposed upon carbonate packstones with crinoids and foraminifers (lithofacies i). The geometry of banding is uninfluenced by the structure of the sediment, despite its heterogeneity. The latter had thus terminated its early diagenetic evolution and induration. This iron-oxide banding could result from remobilization of iron-oxide of lithofacies $i$ due to oscillations of fresh water bodies long after the deposition of the sediment, thus leading to the same interpretation than lithofacies $j$.

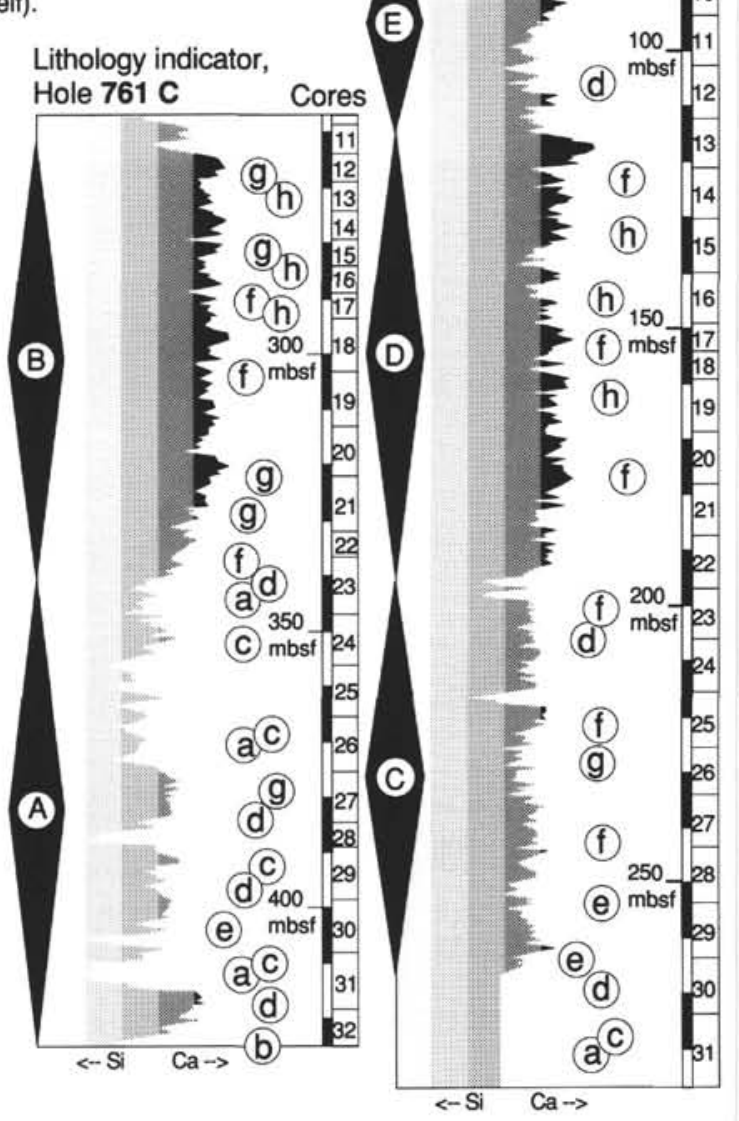

Figure 1. A. Location of the Wombat Plateau and of Sites 759 to 761 and 764 (Leg 122, passive margin) and of Site 765 (Leg 123 , oceanic crust) offshore northwestern Australia. B. Schematic interpretation of seismic line BMR 56-13 across Wombat Plateau, adapted from Williamson et al. (1989), and location of the ODP sites (vertical exaggeration 20x). Vertical hatching: post-rift series. Note the truncation of Upper Triassic beds by the post-rift unconformity (PRU). C. Lithological description of the Rhaetian series at Sites 761 and 764 . The lithofacies ("a" to " $j$ ") are located in front of the geochemical logs (lithology indicator), which show carbonated intervals (blackened peaks) and siliceous intervals (light gray). 
pointing to the most important transgressions during the Late Triassic. These facies occur in the transgressive systems tracts of the Rhaetian formation (see "Sequence Stratigraphy" section, this chapter).

Various carbonate facies are present in the Rhaetian formation. They range from mudstones to grainstones, rudstones, or boundstones as a result of the considerable variability of the environments. They contain different faunal associations corresponding to lagoonal (foraminifers-megalodonts), reefal (brachiopods-calcisponges or corals-calcisponges), or deeper environments (echinoderms-sponge spicules-brachiopods). These facies were affected by a complex diagenetic history, especially because of the influence of freshwater diagenesis, mixed-water dolomitization, and the consequences of syndepositional or postdepositional subaerial exposure. A detailed study of diagenesis is found in Röhl et al. (this volume).

\section{CORRELATION OF THE RHAETIAN SERIES BETWEEN HOLES 761C AND 764B}

The seismic profiles across the Wombat Plateau show strong and fairly continuous reflectors in the Rhaetian sequence. These continuous reflectors are interrupted in some places, however, coinciding with patchy reefal buildup (especially at Site 764; Williamson et al., 1989). It is of major interest for the understanding of tectonic evolution and eustasy to correlate the Rhaetian beds-the most recent below the PRU-between Sites 761 and 764 . The Rhaetian sequence at Site 761 can be schematically divided into two members (Fig. 1C). The lower member A is transgressive and shows open-shelf facies and faunas; the upper member B is regressive and dominated by restricted shallow-platform carbonates. Site 764 is made up of four members: from bottom to top, member $\mathrm{C}$ is shallow marine (except at its very base) with frequent reef development and rare marly layers, member D is more restricted and calcareous, member E is still calcareous but more external than member D, and member F contains marls and limestones of outer shelf origin. According to microfacies and biogenic content (see following sections), two hypotheses concerning correlations between Sites 761 and 764 can be considered.

Hypothesis 1: Members A and B at Site 761 correspond respectively to members $C$ and D at Site 764. Members E and $\mathrm{F}$ do not exist at Site 761 . The series recovered in both holes (members A and B, C and D) is 5\% thicker at Site 764 than at Site 761.

Hypothesis 2: The top of member B at Site 761 corresponds to the top of member E at Site 764. Member F does not exist at Site 761. The series recovered in both holes (members A and $\mathrm{B}, \mathrm{C}$ to $\mathrm{E}$ ) is $25 \%$ thicker at Site 764 .

Hypothesis 1 is preferred here for the following reasons:

1. As documented in the following sections, the microfacies and depositional environments of member D are similar to those of member B. On the contrary, biogenic content (sponge spicules, crinoids, brachiopods) and microfacies of member E (Site 764, especially Cores $122-764 B-13 R$ to $-11 R$ ) are significantly different from those of the upper member B (Site 761). This is also noticed by Zaninetti et al. (this volume). Together with the decreasing percentage of coral elements (Sarti et al., this volume), the development of stalked crinoids in member $\mathrm{E}$ indicates a transgressive character with regard to member D. (Jurassic stalked crinoids need at least $80 \mathrm{~m}$ water depth to develop, according to Roux et al., 1988.)

2. The well logs, which are of major interest regarding the poor recovery of Rhaetian carbonates, must be taken into consideration in the correlation. Holes $761 \mathrm{C}$ and 764B were logged through the drill pipe using the gamma-ray spectrometry tool (GST), which gives the relative amounts of $\mathrm{Ca}, \mathrm{Si}$,
$\mathrm{Cl}, \mathrm{Fe}, \mathrm{H}$, and $\mathrm{S}$ (see Pratson et al., this volume; Borella et al., this volume). Three original curves, shown in Figure 2, were used: $\mathrm{Si} /(\mathrm{Si}+\mathrm{Ca}$ ) (lithology indicator), $\mathrm{Cl} / \mathrm{H}$ (salinity indicator), and $\mathrm{H} /(\mathrm{Si}+\mathrm{Ca})$ (porosity indicator). Note that hypothesis 1 corresponds to a very good fit of these geochemical logs between Sites 761 and 764 (Fig. 2).

Considering the fact that there is only minor thickening between Sites 761 and 764 during the deposition of members $\mathrm{A}, \mathrm{B}, \mathrm{C}$, and D (less than $10 \mathrm{~m}$, according to the proposed correlation), and that the Rhaetian sequence is capped by the PRU, which is markedly erosional farther south, it is reasonable to assume that the uppermost Rhaetian series (member F and probably member E) has been eroded at Site 761 .

\section{SEMIQUANTITATIVE THIN-SECTION ANALYSIS}

Within each thin section the relative abundance of some selected bioclastic elements and sedimentary structures was visually estimated. The results are plotted on top of the log (lithology indicator, which shows the carbonate vs. silica content) of each site. The diagrams of the two sites are superimposed (Fig. 3). The best fit between the diagrams is obtained when members A and B at Hole $761 \mathrm{C}$, respectively, correspond to members C and D at Hole 764B, and when the diagram of Hole 764B is slightly compressed vertically (which means that the series is about 5\% thicker than at Site 761). Some elements show fairly good correspondence between both sites (right side of Fig. 3), and the limits between members $\mathrm{A}$ and $\mathrm{B}, \mathrm{C}$ and $\mathrm{D}$, or D and $\mathrm{E}$ are clearly apparent. The most transgressive intervals (members $\mathrm{A}, \mathrm{C}, \mathrm{E}$, and especially lower F) contain sponge spicules, crinoids, and brachiopods. The most regressive intervals contain the foraminifer Triasina hantkeni Majzon and stromatolites (members B and D). Some other elements show significant differences between both sites (left side of Fig. 3). These differences do not imply that the chosen correlation is invalid; instead they are explained by the stronger development of building organisms (patch-reef) at Site 764, and by the deeper "back-reef" (or actually, “inter-reef”) situation at Site 761 .

\section{MICROFACIES ANALYSIS}

The Rhaetian thin sections from Holes $761 \mathrm{~B}$ and $761 \mathrm{C}$ and from Holes 764A and 764B (about 200 samples) were separated into 19 microfacies types and divided into five groups of microfacies. These microfacies types are described below and some of them are illustrated in Plate 1. For each site, all microfacies represented in each core are plotted. The relative abundance of each microfacies is not taken into consideration because the recovery was poor and presumably selective. As with the quantitative thin-section analyses, the diagrams of the two sites are superimposed using the correlation of hypothesis 1 (Fig. 4)-that is, by reducing the vertical scale of the diagram of Site 764 by $5 \%$. The two sites show similar evolutionary trends and similar shifts near the member A/B limit and the member C/D limit. The strongest difference is observed between upper member A (Site 761, Cores 122761C-26R to -23R: gray marl-limestone alternations with sponge spicules) and upper member C (Site 764, Cores 122$764 \mathrm{~B}-26 \mathrm{R}$ to $-22 \mathrm{R}$ : biogenic carbonates with tabulozoan-hydrozoan communities and Retiophyllia-dominated coral communities, Sarti et al., this volume). This difference also appears in the percentage of carbonates (logs on both sides of Fig. 4) which is higher at Hole 764B. Thus, according to the proposed correlation, the environments during the deposition of upper member A and upper member $\mathrm{C}$ were significantly shallower at Hole 764B than at Hole 761C. This could be explained in a transgressive context (catch-up type sedimen- 


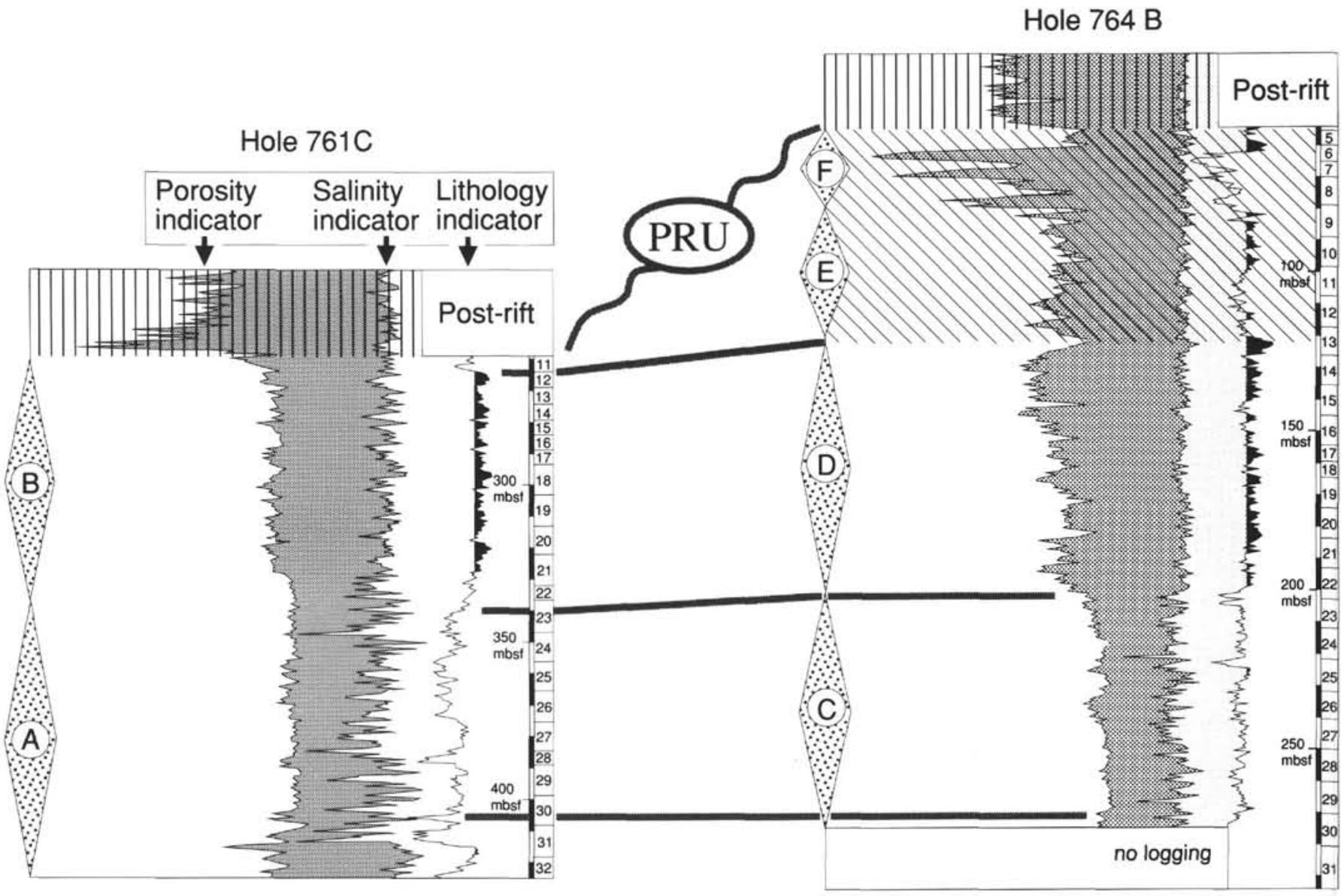

Figure 2. Geochemical well logs of the Rhaetian series at Sites 761 and 764 (gamma-ray spectrometry tool, GST). The correlation hypothesis which is preferred in this chapter, and which is based upon sedimentological criteria (see discussion in text), is represented here. It is in good agreement with log data. Note the sharp change of logs between members A and B (Site 761) and between members C and D (Site 764). This supports the correlation of the $\mathrm{A} / \mathrm{B}$ boundary with the $\mathrm{C} / \mathrm{D}$ boundary. Salinity indicator: $\mathrm{Cl} / \mathrm{H}$. Lithology indicator: $\mathrm{Ca}$ increases to the right (blackened peaks), Si to the left. Vertical hatching: post-rift series. Oblique hatching: interval of Rhaetian series which is preserved only at Site 764.

tation) by the faster carbonate productivity of isolated reefal buildups (Hole 764B) which are able to keep pace with relative sea-level rise.

The identification of microfacies types is based upon textures and some components. Crinoids, although reworked, are used as indicators of comparatively deeper environments, as they lived at a minimum depth of about $100 \mathrm{~m}$ (Roux et al., 1988).

\section{Description of Microfacies Types}

Microfacies type 1a: algal mats, generally dolomitized, with bird's eyes and dessication cracks; type 1b: algal-laminated pelletal lime-mud.

Microfacies type 2a: ooid grainstone with foraminifers. Carbonate grains (more than $50 \%$ ooids) are well sorted, partly micritized, and include foraminifers (Triasina hantkeni Majzon and Aulotortus spp.), dasyclad algae, mollusc fragments, and a few echinoderms. Ooid cortex is thin, radiaxial, and partly micritized. Aggregates are observed. Current bedding is frequent; important primary and vuggy porosity is accentuated by later dissolution. Beach or tidal bar environments, periodically exposed (imbrication with microfacies type 1).

Microfacies type $2 \mathrm{~b}$ : ooid quartz grainstone is exceptionally found at the base of Site 761 (intraclast). The cores of ooids generally consist of well sorted, angular detrital quartz grains of $0.5 \mathrm{~mm}$ size.
Microfacies type 3: Grainstone with rounded, moderately sorted carbonate grains and foraminifers. Texture and components are similar to those of type 2a except for ooids, which are exceptional, but micritization is extensive. Rare keystone vugs. Beach to lagoon transition.

Microfacies types 1 to 3 belong to the "beach to tidal-flat" group.

Microfacies type 4: peloid packstone-grainstone with abundant foraminifers. Extensive micritization of carbonate grains (many "peloids" are in fact unrecognizable micritized bioclasts), which include coprolites and pellets. Dasyclad algae are frequent.

Microfacies type 5: peloid packstone with foraminifers. Peloids become dominant because of micritization and pellets are found in significant amounts. Other grains, poorly sorted, include foraminifers (Triasina hantkeni Majzon), molluscs, and dasyclad algae.

Microfacies type 6: peloid packstone with foraminifers, skeletal fragments, and Megalodon shells. The background sediment is similar to that in type 5. The Megalodon shells show an altered, perforated, sometimes encrusted surface. Valves are found isolated or paired. This facies is specific to Site 761.

Microfacies type 7: skeletal-peloid packstone with foraminifers. Contains similar elements to these in type 5 (Triasina 


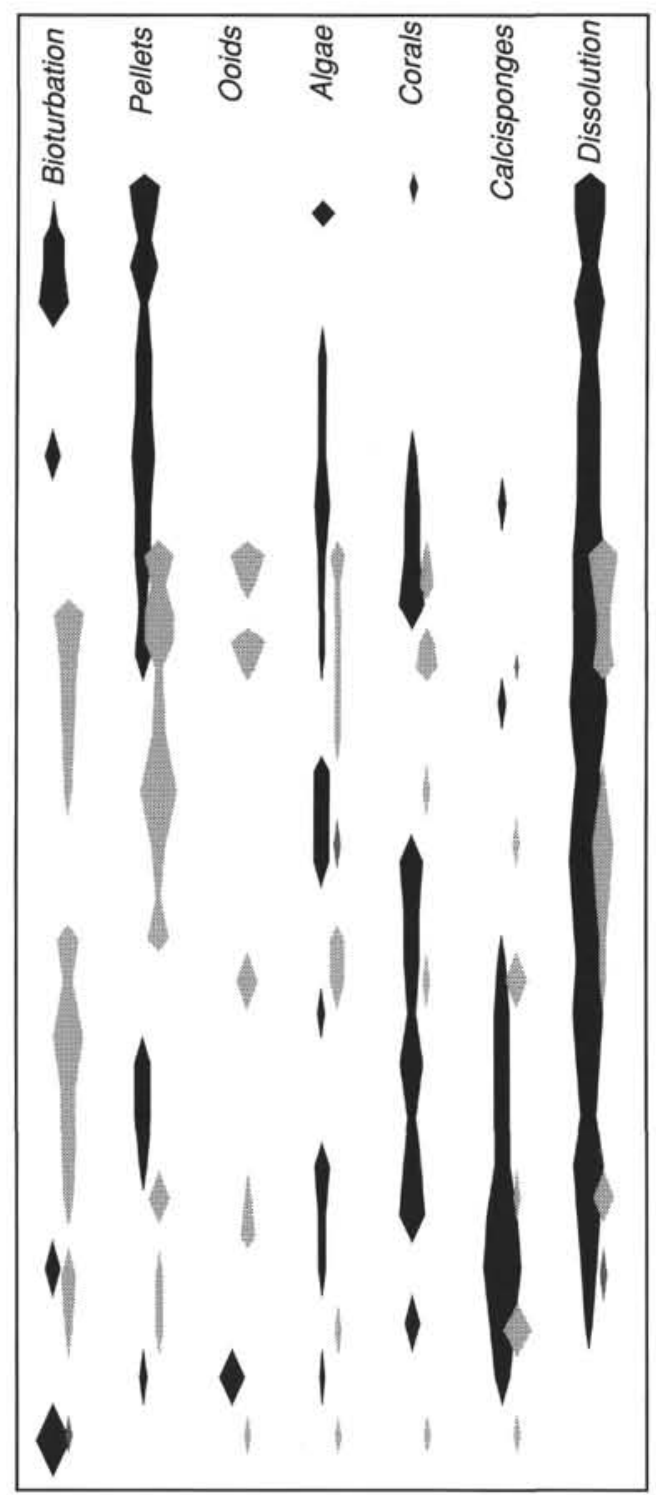

Differences traces $(<1 \%)$
rare $(1-5 \%)$
medium $(5-10 \%)$
frequent $(10-25 \%)$
abundant $(25-50 \%)$
very abundant $(>50 \%)$

Hole

$761 \mathrm{C}$

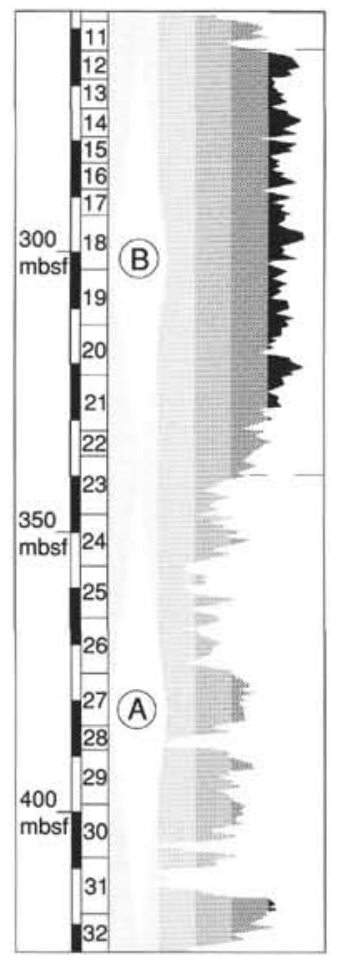

Lithology $(<-S i \quad \mathrm{Ca}->)$

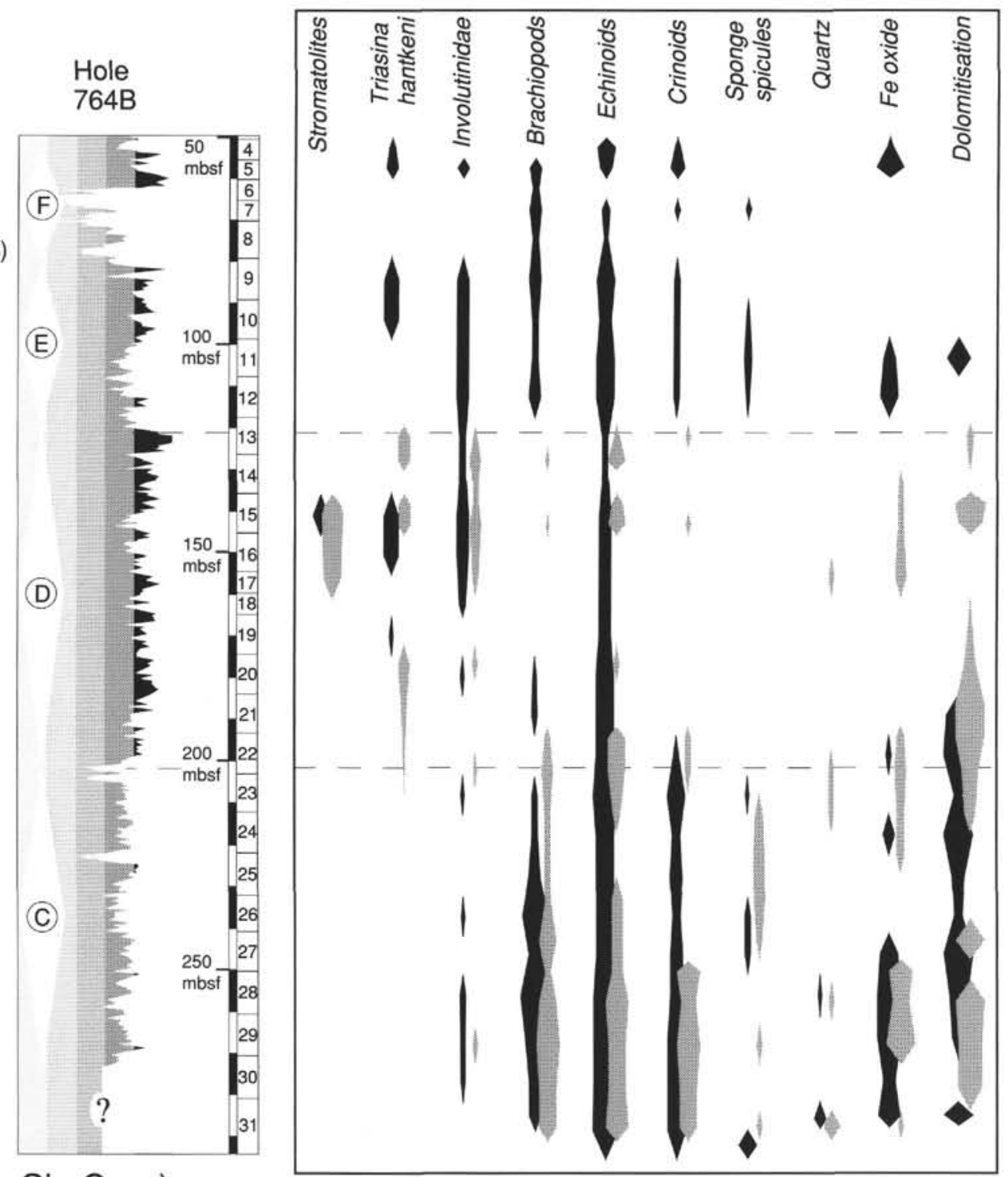

Coincidences

Figure 3. Quantitative inventory of bioclasts and sedimentary structures at Site 761 (gray) and Site 764 (black). The resulting diagrams at Sites 761 and 764 are superimposed to show the comparison. The best fit is obtained when members A and B (Site 761) respectively correspond to members C and D (Site 764), the diagram of Site 764 being slightly compressed vertically indicator: $\mathrm{Ca}$ increases to the right (blackened peaks), $\mathrm{Si}$ to the left. 
hantkeni Majzon, algae, micritized grains, coprolites, and pellets), plus a major proportion of large skeletal elements (pepecypods, gastropods). Geopetal fillings are observed. They correspond to the type 2 internal sediment of Aissaoui and Purser (1983) and occur in intertidal environments.

Microfacies types 4 to 7 belong to the "lagoonal" group.

Microfacies type 8: white carbonate mudstone with sparse, shallow subtidal fauna (gastropods, pelecypods). Darker, halo-shaped patches of micritization are observed that may have been produced by bacterial activity. This microfacies is similar to the mudstone matrix of some coral boundstones.

Microfacies type 9: coral boundstone (see Sarti, et al., this volume, for an extensive study on reefal facies). Branching corals are floating in carbonate mudstone and wackestonepackstone with coral fragments, pelecypods, brachiopods, echinoderms, and green algae. Small calcareous sponges are frequently associated with them. Geopetal fillings and patches of micritization (see type 8) are common.

Microfacies type 10: calcisponge-brachiopod boundstone. Matrix is either carbonate mudstone and wackestone with patches of micritization of probable bacterial origin, or reddish clay (marker bed "e," Fig. 1C). Primary porosity is significant. Associated fauna include brachiopods in life position, sometimes encrusted by sponges, and serpulids. Authigenic dolomite is frequent. These facies, studied by Sarti et al. (this volume), show similarities to those described by Stanton and Flügel (1989) in the Eastern Alps.

Microfacies type 11: skeletal wackestone with coral and sponge fragments, brachiopods, crinoids, and red algae. The matrix resembles those of microfacies 9 and 10 but echinoderms and crinoids increase significantly. Micritization patches and geopetal fillings are still present.

Microfacies 8 to 11 belong to the "patch-reef" group.

Microfacies type 12: skeletal grainstone-rudstone with brachiopods. Allochems are broken, poorly sorted, and show micritic envelopes and sometimes algal crusts. Coral and sponge fragments occur.

Microfacies type 13: crinoid grainstone. At least $30 \%$ of grains are crinoids, together with "peloids" (micritized skeletal grains of unknown origin), brachiopods, and foraminifers (mainly Aulotortus spp., no Triasina hantkeni Majzon). Sorting is good. Ooids are rare (Sample 122-764B30R-1, 64-67 cm). Oncoids are more frequent. Neither laminations nor keystone vugs are observed. This microfacies differs significantly from microfacies 2 and 3 (not connected with tidal flats; stronger marine influence) and indicates a continuous trend to microfacies 14,15 , and 16 (Pl. 1).

Microfacies type 14: crinoid-skeletal packstone. Poorly sorted, coarse bioclasts (1 mm or more) are mostly crinoids and brachiopods, together with dasyclad algae, gastropods, pelecypods, and small foraminifers. Micritization patches, geopetal fillings, and syntaxial (marine) cement are observed. Porosity is mainly due to dissolution.

Microfacies type 15: fine crinoid-peloid packstone, moderately sorted, containing similar elements to those of type 14 , but of smaller size $(<0.5 \mathrm{~mm})$. Many bioclasts are micritized (except crinoids) and hardly identifiable ("peloids").

Microfacies type 16: very fine crinoid-peloid packstone belonging to the same trend as types 14 and 15 (grain size about $0.1 \mathrm{~mm}$ ). Clay and bioturbation appear.

Microfacies 12 to 16 belong to the "shallow outer shelf" group.

Microfacies type 17: calcareous mudstone with thin-shelled molluscs ("filaments") and rare sponge spicules. Weakly bioturbated.
Microfacies type 18: bioturbated calcareous mudstone to marly lime-mudstone with foraminifers (Duostominidae only) and sponge spicules. cules.

Microfacies 17 to 19 belong to the "'outer shelf" group.

\section{SEQUENCE STRATIGRAPHY}

\section{Basal Boundary}

Based on the pollens and dinoflagellates data (Brenner et al., this volume), Core $122-761 \mathrm{C}-32 \mathrm{R}$ contains the boundary between the Norian and Rhaetian. It appears to correspond to a facies boundary between underlying black silt and clay (shallow deltaics), and the overlying marine outer-shelf marl and marly limestone with crinoids. Thus, the sedimentological change either may occur exactly at the time boundary if the sedimentary record is complete or may correspond to a depositional gap in which the time boundary is included. The latter interpretation is confirmed by the following observation: the lowermost Rhaetian crinoid layers contain a rounded lithoclast made of oolitic grainstone whose oolite cores are quartz grains. This lithoclast is reworked into outer-shelf, quartz-rich marly limestones with crinoids, implying that the first Rhaetian beds are erosional (lithoclasts, quartz grains reworked from the underlying formations) and postdate the development of a shallower, quartz-rich carbonate wedge. This leads to the interpretation that the Norian-Rhaetian facies boundary is a sequence boundary coincident with a transgressive surface (sensu Haq et al., 1987). The overlying beds belong to the transgressive systems tract, and the reworked oolitic clast is a remnant of earlier stages of the transgression.

\section{Lower Part (Members A and C, Fig. 4)}

The base of this part is markedly transgressive in both sites. However, at a higher level, deeper microfacies are observed at Hole 761C compared to Hole 764B which is indicative of the major development of coral-rich carbonates. This can be explained by differences of carbonate accumulation rate between (1) the reef environments, which were initially developed at both sites (sponge boundstones, microfacies 10) but grew into coral reefs only at Hole 764B, and (2) non-reefal environments of Site 761. According to Gildner and Cisne (1989), the water depth is a function of the ratio between the rate of sea-level rise and the maximum sediment accumulation rate which is higher in reefal environments. Thus, for a given rate of sea-level rise during the deposition of members $\mathrm{A}$ and $\mathrm{C}$, a greater water depth is expected outside of the patch-reefs (Hole 761C, member A) because of the slower carbonate accumulation rate. In addition, the relative sealevel rise and its fluctuations are better recorded by this drowned series (Hole 761C), whereas the reefal buildups (Hole 764B), which remain at sea level, are no longer able to show variations in water depths and environments (Gildner and Cisne, 1989). Thus, based mainly upon Hole 761C data, members $\mathrm{A}$ and $\mathrm{C}$ are interpreted as belonging to a transgressive systems tract composed of several parasequences which appear on the log of Hole 761C (Fig. 4, left side). On this log the peaks of the successive parasequences become less and less carbonated toward the top (displaced to the left). This should represent retrogradation leading to maximum flooding in upper members $\mathrm{A}$ and $\mathrm{C}$; this corresponds well to the microfacies interpretations (Fig. 4). At the top of members A and $\mathrm{C}$, a marker layer of yellowish limonite-rich marl is observed (Sections 122-761C-23R-1 and 122-764B-22R-1), which could correspond to the maximum condensation. If this 


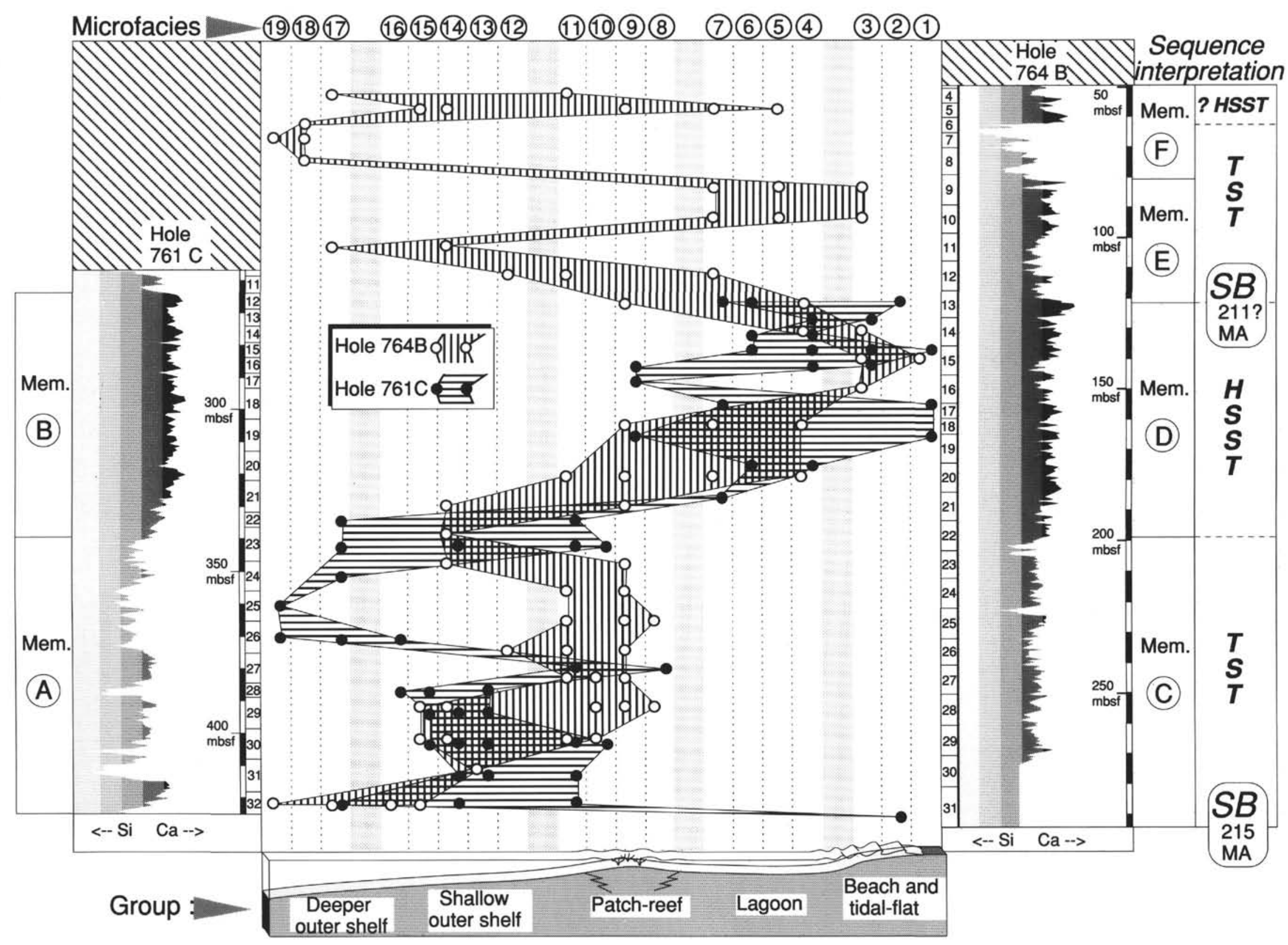

Figure 4. Microfacies evolution curves of Sites 761 and 764 (microfacies described in the text and in PI. 1). The two diagrams are superimposed and the correlation is the same as in Figure 3. Note the good fit between microfacies evolution and logs (lithology indicator). An interpretation of systems tracts is proposed to the right of the figure. HSST = highstand systems tract; TST = transgressive systems tract; SB = sequence boundary. 


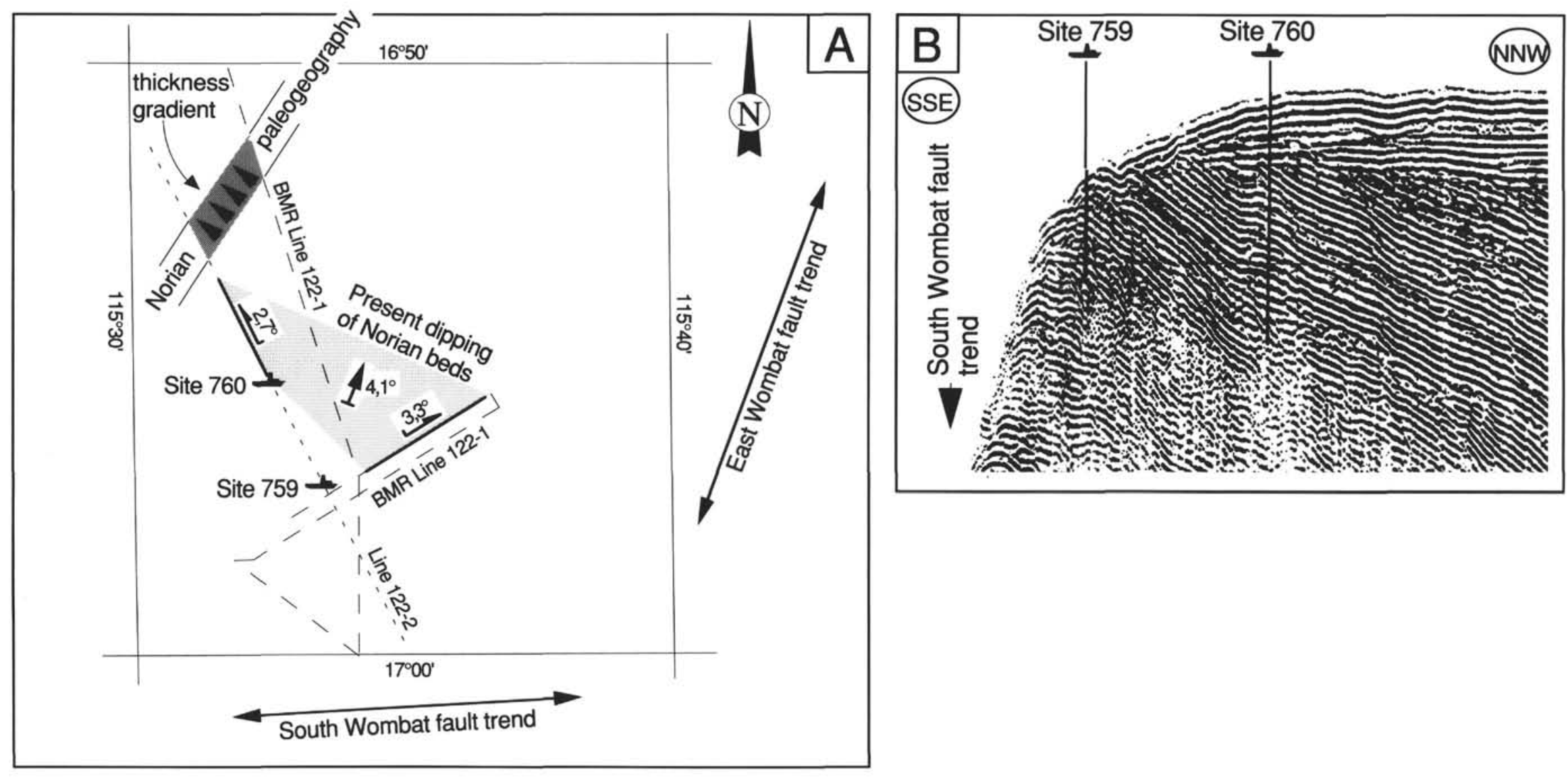

Figure 5. Geometrical relations between Upper Triassic sedimentary bodies, unconformities, and the PRU in the southern Wombat Plateau. A. Traces of seismic lines BMR 122-1 and 122-2. First, the present-day dipping of Norian beds around Sites 759 and 760 is determined using two perpendicular lines. It is found to be $4.1^{\circ}$ toward the north-northeast. It is most likely influenced by the South Wombat fault trend which runs parallel to the continent-ocean boundary of the Argo Abyssal Plain. Second, the direction of Norian depositional trends and paleogeography is evaluated by joining the same thicknesses and seismic signatures of Norian carbonate layers (recovered in Site 760, Cores 122-760B-6R to -17R) between two subparallel lines. This trend is approximatively northeast-southwest, which is coherent with published data concerning the Triassic paleogeography of the Northwest Shelf of Australia (see text). It is not related to present-day dipping and was more likely influenced by the activity of the East Wombat fault trend. B. Part of seismic line 122-2: tilting and erosion of Upper Triassic beds are maximum approaching the South Wombat fault and are evidently linked to the activity of this fault. But Norian layers are more or less isopaquous and are not significantly thickening northward although the profile is perpendicular to the South Wombat fault. This shows that the South Wombat fault was not active during the Triassic, but is more recent. 
sequence interpretation is correct, the paleodepth and facies differences between upper member A (Site 761) and upper member C (Site 764) are the result of a different response to an increase of accommodation potential (Posamentier and Vail, 1988; Sarg, 1988).

\section{Middle Part (Members B and D, Fig. 4)}

This part shows more homogenous facies at both sites, which is also expressed by the similarity of chemical logs (Fig. 2 and 3). However, microfacies indicate that Site 761 corresponds to slightly more restricted environments (Megalodons, ooids, etc.). Member B is shallowing upward (progradation), because tidal flats are observed only in its upper part. Evidences of subaerial exposure and non-marine cementation are frequent. The widespread platform carbonate sedimentation was able to keep pace with sea-level change. Members B and $\mathrm{D}$ are interpreted as belonging to a highstand systems tract.

\section{Upper Part (Members E and F, Fig. 4)}

The interpretation of this part is more problematic because (1) it is preserved only at Site 764 , and (2) it is possibly truncated at its top by the PRU. As mentioned above, member $\mathrm{E}$ is transgressive with regard to $\mathrm{D}$, and the deepest environments, which are observed in the lower member F (Cores $122-764 \mathrm{~B}-8 \mathrm{R}$ to $-6 \mathrm{R})$, are comparable to those of the maximum flooding of member A at Site 761. Member E and lower member F (Cores 122-764B-12R to -6R) are interpreted as a new transgressive systems tract and the limit between members $\mathrm{D}$ and $\mathrm{E}$ as a sequence boundary superimposed on a transgressive surface. Overlying cores are difficult to interpret because they correspond to a wide microfacies range and show evidence of both shallowing and condensation. It should represent a condensed interval which anounces either the transition toward an unpreserved highstand or the appearance of an anomalous sedimentation state (starved submarine high).

\section{Extensional Tectonics or Global Eustasy?}

These sequence interpretations do not definitely identify global eustasy as the major causal factor, as relative sea-level changes are produced by local tectonic subsidence as well. However, actual evidence of Rhaetian syn-sedimentary tectonics that can disturb the arrangement of the sedimentary bodies is lacking in the Wombat Plateau area: differential subsidence, basins and shoals, and angular unconformities are never observed on the seismic record of Rhaetian beds. In addition, the lateral continuity of the Rhaetian layers seems very good (as shown by seismic data and by the proposed correlation) and their thickness fairly constant.

The only indication of syn-sedimentary tectonics is found at or below the very base of the Rhaetian series and consists of small, normal faults that delimit slightly upthrown blocks upon which coral patches have sometimes developed (Williamson et al., 1989). This extensional tectonic event is, however, of a lower order of magnitude than that which affected Carnian deposits and it is sealed by the lower Rhaetian beds. It is possible that this late Norian-earliest Rhaetian tectonic event initially influenced the location of the coral patches, which probably settled on paleohighs. But the initiation, development, and end of the Rhaetian reef growth are primarily controlled by accommodation space and need a Rhaetian relative sea-level rise. The causal link between the late Norian-earliest Rhaetian small faults and paleohighs and this Rhaetian sea-level rise is not demonstrated. Furthermore, the proposed correlation and the seismic data show that there is no significant thickness difference for the total Rhaetian series between a reef position (Hole 764B) and a non-reef position (Hole 761C). Since the paleo-water depths are com- parable, the reef growth was not caused by differential tectonic subsidence.

Moreover, the lower sequence boundary observed in the Rhaetian series of the Wombat Plateau, which is near the Norian-Rhaetian boundary (Brenner, this volume), is consistent with the 215-Ma global sequence boundary of the cycle chart (Haq et al., 1987), and the upper sequence boundary (between members D and E) is a good candidate for the 211-Ma global sequence boundary, which is still Rhaetian. Thus, the systems tracts and sequence boundaries of the Rhaetian series of the Wombat Plateau were strongly influenced by a global cause, which could have been global eustasy. Some tectonic processes may also have been involved if they were synchronous worldwide, such as variations of intraplate stresses proposed by Cloething (1986), but local tectonics alone was unsufficient to create the observed unconformities and changes of depositional environment.

\section{WHAT HAPPENED AFTER THE RHAETIAN?}

This was a major objective of Leg 122. At least two scenarios were considered to explain the relationship between the neritic uppermost Triassic carbonates and the pelagic Lower Cretaceous sediments: either (1) the Wombat Plateau was drowned in deep water in the earliest Jurassic and remained in pelagic marginal plateau environments during the entire Jurassic (bottom currents and trapping of sediments into nearshore basins are put forward to explain the depositional gap), or (2) the Wombat Plateau was subaerially exposed and partly eroded during the Jurassic. Unfortunately, the four sites could give no definite answer. However, there are some arguments in favor of the second explanation:

1. This chapter shows that the PRU is erosional not only at southern sites (that is, near the fault scarps) but also in the central Wombat Plateau (about $70 \mathrm{~m}$ of carbonates eroded at Site 761); this is not very consistent with the first explanation.

2. Two diagenetic features observed at Site 764 could result from subaerial exposure long after deposition (Röhl et al., this volume): the first one (lithofacies " $j$," Fig. 1) consists of an extensive recrystallization of marine packstones and wackestones with crinoids, which postdates hardening and fracturing of the sediment, and which shows a sharp ferruginous front. Some radial or parallel arrangement of the elongated calcite crystals may indicate a pedogenetic origin. The second one (lithofacies " $k$," Fig. 1) is a regular, anastomosing millimetric banding of iron oxide which is superimposed upon marine crinoid packstones. The iron oxide bands, which are not sedimentary layers, can cross through some bioclasts (i.e., crinoids) or can merge with some big pelecypod shells as a result of shelter effect. They are tentatively interpreted as the result of iron oxide remobilization and reprecipitation by an oscillating freshwater lens into a hardened, porous sediment. These two late diagenetic features occur a few meters below the erosional PRU at Holes 764A and 764B.

3. Von Rad et al. (in press) describe dredged rocks from the northern edge of the Wombat Plateau which were not recovered at Site 764, and which must be younger than the youngest sediments below the PRU at this site; they contain subaerially emplaced volcanics, which show that the plateau was not drowned at that time.

The second explanation is therefore more likely, and it is coherent with other regional data which show that (1) Upper Triassic beds are very frequently eroded by the so-called "main unconformity" and unconformably overlain by the Lower Cretaceous on the Exmouth Plateau (Vincent and Tilbury, 1988) as well as on Scott Plateau (Middleton, 1988; 


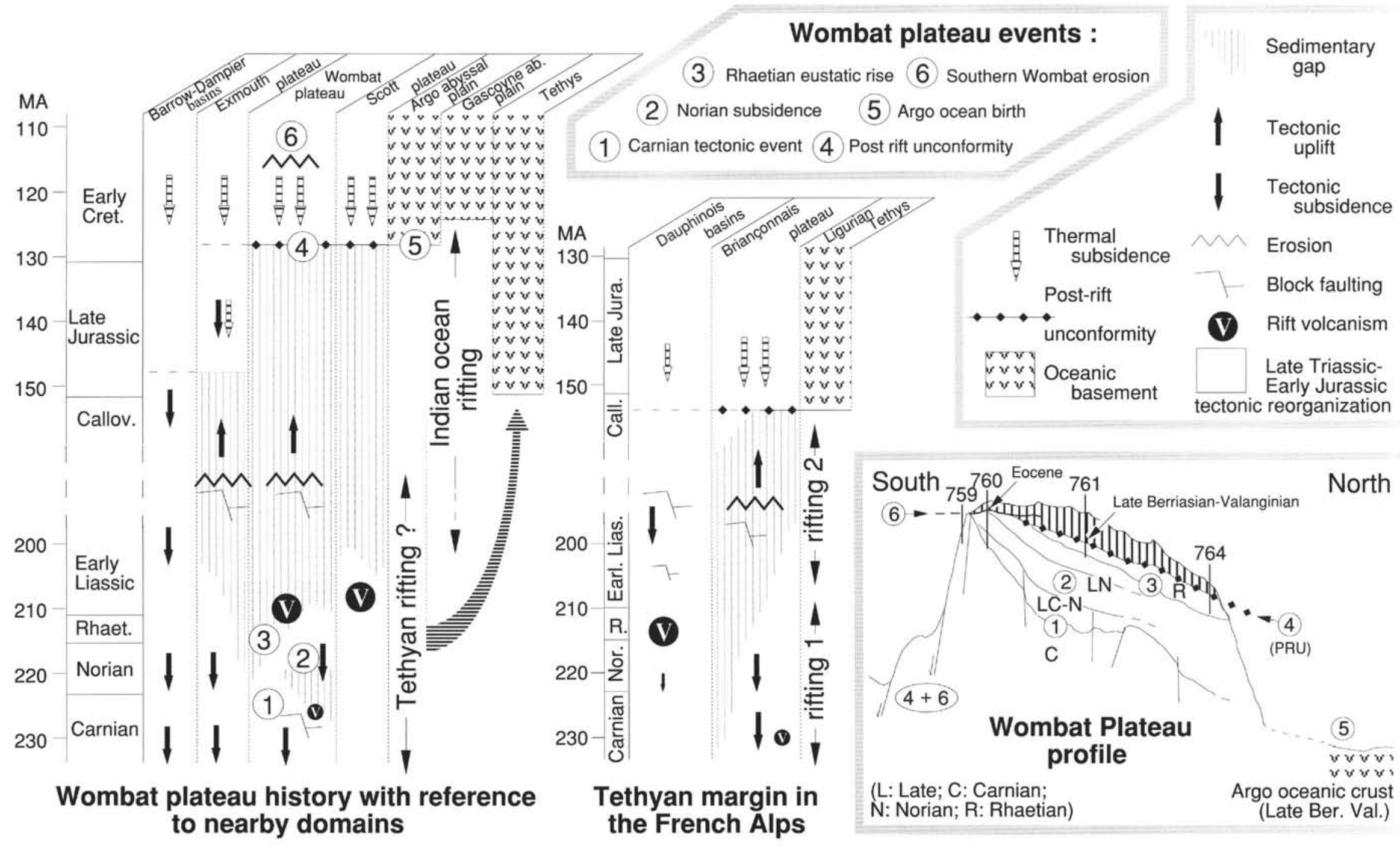

Figure 6. Chronology of events in the Wombat Plateau area based upon the Leg 122 data, and comparative evolution of part of the Northern Tethyan margin in the French Alps. The Triassic-Jurassic boundary appears in both cases as a key period of major tectonic reorganization: shift of subsidence patterns, birth of marginal plateaus, and rift volcanism. 
Bint, 1988), and (2) when some Jurassic is observed in these areas, it consists either of neritic Hettangian (Bint and Helby, 1988; Bint, 1988, and pers. comm., 1989) or of deeper marine Upper Jurassic. The "main unconformity" can be traced in the sediments of the Barrow-Dampier basins, where it is of Callovian to Tithonian age (Vincent and Tilbury, 1988). The Wombat Plateau has probably experienced the same history as the Exmouth Plateau and had not significantly drowned before the Late Jurassic.

\section{GEOMETRY OF SEDIMENTARY SEQUENCES AND UNCONFORMITIES: AGE OF EXTENSIONAL TECTONICS IN THE WOMBAT PLATEAU AREA}

Block faulting, tilting, and erosion have had a major influence on the organization of some of the sedimentary sequences of the Wombat area since the Triassic, and tectonic subsidence itself began in Permian times (Williamson and Falvey, 1988). But because the sedimentary record is interrupted during the Jurassic, it is difficult to determine whether this tectonic activity was continuous throughout the whole Mesozoic or whether it occurred in several different pulses. The Wombat Plateau is now bounded by major normal faults and grabens, both on its southern (South Wombat fault trend) and on its eastern edges (East Wombat fault trend). Both these fault trends, which delimit the Montebello Canyon, are likely to have been involved during the rifting events. The threedimensional geometric relationships between sedimentary bodies and unconformities cannot be understood using one single north-south profile across the Wombat Plateau (seismic line 56-13 of the Australian Bureau of Mineral Resources, BMR, Fig. 1B), which best shows east-west structures. Thus, several perpendicular and parallel segments of lines 122-1 and 122-2 were used. As shown in Figure $5 \mathrm{~A}$, the present-day dipping of Upper Triassic (Norian) beds around Site 760 on the one hand, and the direction of maximum thickness and facies gradients of Upper Triassic sequences on the other, which appear linked on the north-south profile, are in fact oriented differently (nearly perpendicular). Thus, to consider the apparent northward dipping of the Upper Triassic beds on the north-south profile as a relic of Late Triassic dipping is an oversimplification. Several different tectonic pulses actually affected the Wombat Plateau area, and this has major implications for the understanding of rift tectonics.

During the Late Triassic, the platform faced toward the northwest, as shown also by Exon et al. (1982), Williamson et al. (1989), and von Rad et al. (1989b). North-northeast, southsouthwest to northeast-southwest faults were active at that time (i.e., the East Wombat fault or the Swan Canyon graben; Exon et al., 1982) but no actual evidence of activity along the South Wombat (east-west) fault trend has been found (Fig. 5B).

After the latest Triassic and before deposition of the first beds above the PRU at Site 760 (before the Eocene) the Upper Triassic beds were tilted toward the north-northeast and eroded, a result in part of the activity of the South Wombat fault and the creation of the South Wombat graben which separated the Exmouth and Wombat plateaus.

The record at Site 761, which is more complete above and below the PRU than at Site 760, gives more details about this history. Here, (1) the influence of the South Wombat (eastwest) fault is weaker than at Site 760 (nearly conformable across the PRU; weaker tilting), and (2) the first beds above the PRU, which are older than at Site 760 (lowermost Cretaceous), are tilted. That means that the South Wombat fault was still active after the earliest Cretaceous although it could have been active earlier. In addition, a Lower Cretaceous siliciclastic wedge overlying the PRU was recovered at Site 761 (10 $\mathrm{m}$ of upper Berriasian to lower Valanginian hemipelagic- deposited ferruginous sand with belemnites; Cores 122-761A$30 \mathrm{X}$ and 122-761B-10R): this wedge cannot represent the northward tongue of the Barrow Group (Boote and Kirk, 1989) since the Wombat Plateau was not connected to the Exmouth Plateau at that time (von Rad and Thurow, this volume). Thus, the siliciclastic material (reworked from the Late Triassic) comes from the Wombat Plateau itself and especially from its southern edge where the blanket of Rhaetian carbonates has been eroded. This provides evidence of the activity of the South Wombat fault during or a little before the Early Cretaceous.

These arguments lead to the following conclusions:

1. The Wombat Plateau cannot be considered as one simple and fixed north-facing margin edge throughout the Mesozoic that experienced a continuous rift evolution from the Late Triassic to the birth of the oceanic crust in the Argo Abyssal Plain 100 m.y. later. The tectonic evolution was more complex and included several pulses probably related to several continental breakups.

2. The Upper Triassic northwest-facing margin was dominated by north-northeast, south-southwest to northeast-southwest faulting. No evidence of east-west faulting is found at that time. This is consistent with the overall evolution of the Exmouth Plateau.

3. The orientation of tilting and faulting during the Jurassic cannot be characterized with the available data and must be deduced from other regional studies.

4. East-west faulting and the correlative creation of the South Wombat graben possibly started in earliest Cretaceous and certainly developed during the middle to Late Cretaceous, together with the development of the Argo Abyssal Plain.

\section{COMPARISONS WITH EUROPEAN TETHYAN MARGINS}

Many similarities are found between the study area and some European series which also belong to Mesozoic Tethyan margins. Three examples concerning carbonate sedimentology, sequence history, and tectonic/geodynamic evolution are given below.

\section{Carbonate Sedimentology}

The Rhaetian microfacies found offshore Australia and their distribution are similar in part to those described in Central Europe (Piller, 1981; Schott, 1983). The calcispongetabulozoan facies encountered in members $\mathrm{A}$ and $\mathrm{C}$ resemble some Steinplatte mound facies described by Stanton and Flügel (1989). The general distribution of organisms on the platform corresponds to several published models of Upper Triassic carbonate platforms (Piller, 1981; Flügel, 1981; Di Stefano and Senowbari-Daryan, 1985): crinoids, then brachiopods, are found in the most distal position; calcisponges appear in a somewhat shallower zone and predate the development of coral patches; Megalodons and Triasina hantkeni Majzon are extensively developed in the back-reef position (or between patch reefs).

\section{Sequence Evolution}

With the exception of near-continental areas (i.e., southern France), the Rhaetian sequence in Europe shows generally a sharp basal transgression, a terrigenous-rich, marine lower part, and a carbonate-dominated upper part in which patchreefs and tidal flats are developed (Lualdi, 1983; Dumont, 1988; Accordi, 1976; Thery et al., 1989). Thicknesses are of the same order as in the Wombat Plateau area $(100-300 \mathrm{~m})$ except in Lombardy, where drastic extensional tectonics have produced a 1-km-deep graben (Massetti et al., 1989). There is, however, one difference between European and Australian 
Rhaetian series: in the latter, a sequence boundary is found inside the upper part of the series (Site 764), whereas in the former, the top of the highstand carbonates is supposed to coincide with the Triassic-Jurassic boundary. Two explanations are possible: (1) this difference is real, and thus the intra-Rhaetian sequence boundary of the Wombat series may be due to tectonic subsidence and not to global eustasy, or, more probably, (2) this difference is an artifact of the difficulties in dating the lowermost Hettangian in the European series: the first beds overlying the facies boundary are generally undated or their age is poorly documented (Cantaluppi and Lualdi, 1983; Dumont, 1988); precise dating shows that the time boundary does not coincide exactly with the facies boundary (Mettraux and Mohr, 1989).

\section{Geodynamic Setting}

The Wombat Plateau series were deposited on a marginal plateau which was affected by several rifting pulses throughout the Mesozoic (Fig. 6). They recorded first an extensional tectonic event somewhere in the Carnian, connected with and followed by significant subsidence, then a major tectonic shift soon after the Rhaetian, which produced (1) volcanism (Wombat Plateau: von Rad et al., 1989b; von Rad et al., in press; Scott Plateau: Bint, 1988), and (2) a drastic change of the subsidence pattern and the birth of nearshore basins (BarrowDampier) and marginal plateaus (Exmouth, Scott). The same events are recorded at the same time on the "fossil" European passive margin of the Ligurian Tethys presently imbricated in the Western Alpine nappes and European foreland (Fig. 5C): "Carnian tectonic crisis" (Megard-Galli and Baud, 1977; Megard-Galli and Faure, 1988), volcanism close to the Triassic-Jurassic boundary (France: Laurent, in press; Curnelle and Cabanis, 1989; Spain: Lago, 1984), and contemporaneous major reorganization of the subsidence pattern coupled with a change of stress orientation (Grand, 1988). This led to the individualization of Jurassic nearshore basins and marginal plateau, the so-called Briançonnais domain (Lemoine et al., 1986; Faure and Megard-Galli, 1988; Dumont, 1988). As a result, the Upper Triassic-Jurassic series observed in the latter domain are very similar to the Wombat and Exmouth Plateau series, and have experienced a similar evolution: strong Norian subsidence balanced by sedimentation; Rhaetian transgressino; earliest Jurassic, locally preserved, shallow marine beds; later (pre-Callovian) extensional tectonics; subaerial exposure and erosion; and final drowning as a result of thermal subsidence when the first oceanic crust appeared. Furthermore, this evolutionary history is not exceptional, as it resembles the Suez Rift development, for example (Dumont and Grand, 1987).

\section{CONCLUSIONS}

Legs 122 and 123 have significantly modified the ideas about the geodynamic evolution of the northern part of the Exmouth Plateau. First, there are probably no Jurassic deposits preserved in the Wombat Plateau area and there were certainly no thick syn-rift Jurassic series. Second, the oceanic crust north of the Wombat Plateau is not a true Tethyan one, but results from the Early Cretaceous (latest BerriasianValanginian) breakup of an unknown continental block ("Argo landmass," Gradstein et al., 1989) just before the Neocomian Indo-Australian breakup. Thus, the data of Legs 122 and 123 document Late Triassic extension and subsidence on the one hand, and the birth of the Argo ocean and the correlative development of the PRU in the passive margin on the other. But these two events cannot be included a priori in the same evolutionary trend, especially considering the lack of information about Jurassic events. In particular, it is not obvious that the northern part of the Wombat Plateau, which is at present the edge of the continental margin, was already the edge of a Tethyan platform during the Late Triassic.

This study drew attention to the following points: (1) the Late Triassic margin did not face northward (that is, toward the present northern edge of the Wombat Plateau and the Argo ocean) but northwestward, (2) the most recent deposits below the PRU (Rhaetian) were not significantly thickened or faulted during deposition approaching the present-day continent/ ocean boundary, and (3) the environments are different at Site 764 because at this site we recovered one of the numerous reefal buildups that are commonly found in the Rhaetian series where these series are preserved (northern Wombat Plateau; Williamson et al., 1989), but not because Site 764 was located on a reef belt at the Triassic platform edge (reefal buildups are also found southward from Site 761; Williamson et al., 1989).

Thus, the Upper Triassic sequences of the Wombat Plateau do not really indicate the proximity of a margin edge and they do not correspond to syn-rift deposits with respect to the Argo ocean. It is likely that the continental breakup northward from the Wombat Plateau, which gave birth to the Argo oceanic crust, was not initiated during the Late Triassic, but later.

It is proposed that the Wombat Plateau area experienced two different rift phases (Fig. 6):

1. A Tethyan rift phase which began in the Late Triassic (or even earlier) and was responsible for the Carnian tectonic pulse, and then the development of Jurassic nearshore basins and a rim of marginal plateaus (Exmouth, Wombat, Scott). This rift phase is likely to have produced the Jurassic breakup of northern Gondwanan continental blocks (Purcell and Purcell, 1988).

2. A second (earliest Cretaceous) rift phase which "stamped out" the previous Tethyan margin and its rim of plateaus, and whose effects upon the Wombat Plateau were both renewed uplift and erosion after the Jurassic breakup and before the Argo then Gascoyne breakups, and activation of transverse fault zones (South Wombat fault, North Wombat transform continent/ocean boundary). This model fits (1) the tectonic and sedimentary history of the Wombat Plateau during the Late Triassic, which has to be regarded as pre-rift with respect to the Neocomian breakup, (2) the long duration of the sedimentary gap below the PRU, which commenced with the development of the marginal plateaus of the first rift phase and ended only with the breakup of the second rift phase, and (3) the age of the oceanic crust at Site 765 (Leg 123: Gradstein et al., 1990; Marcoux and Baumgartner, in press), which was younger than expected.

In regard to sequence stratigraphy, two sequence boundaries are documented: the lower one near the Norian-Rhaetian boundary and the upper one within the upper part of the Rhaetian beds at Site 764. Relative sea-level rise could be produced either by tectonic subsidence or by an eustatic rise, but no local evidence showing significant Rhaetian tectonics was found. Furthermore, a similar sequence evolution is observed in some Rhaetian series far from the Australian margin (i.e., in the "stable" part of the northern Tethyan margin in western Europe (French western Alps)), with comparable facies evolution and thickness. This suggests that Rhaetian systems tracts are mostly influenced by global sea-level changes. However, the origin of the second, intra-Rhaetian sequence boundary, which is not observed in Europe, is less certain. It could correspond to the late Rhaetian (211 Ma) sequence boundary of the global cycle chart (Haq et al., 1987), but it could also be enhanced by local tectonic subsidence.

The Rhaetian transgressions occur close to a major tectonic reorganization that produces drastic paleogeographic 
changes all over the northwestern Australian margin, as well as local volcanism. Some other passive margins are also concerned by such events: latest Triassic-earliest Liassic paleostress reorientation synchronous with short-lived fissural volcanism and paleogeographic changes documented in the Western Alps (Grand, 1988), and the widespread Rhaetian-Hettangian short-lived volcanism (North America: Manspeizer, 1988; Sutter, 1989; Spain: Lago, 1984; southern France: Curnelle and Cabanis, 1989) which coincides with a tectonic reorganization on the North American margin (Venkatakrishnan and Lutz, 1988; Klitgord et al., 1988). The synchronism of these events is noticeable and it is likely that the tectonic and magmatic events which are recorded in the Wombat Plateau area around the Triassic-Jurassic boundary (latest Triassic to earliest Jurassic volcanism, uplift of the plateau) should not be regarded as local events as opposed to global eustasy, but are an expression of a worldwide geodynamic activity which is certainly not independent of global eustasy. This could explain the difficulties in evaluating the influence of tectonics and global eustasy upon margins such as northwestern Australia, especially if the effects of both are superimposed.

\section{ACKNOWLEDGMENTS}

The author would like to thank Roman Koch (Erlangen) and Marcel Lemoine (Villefranche S/Mer) for their constructive criticism and help in improving the manuscript.

\section{REFERENCES}

Accordi, G., 1976. Il Retico dei Monti Martani (Perugia). Boll. Soc. Geol. Ital., 95:3-26.

Aissaoui, D. M., and Purser, H. B., 1983. Nature and origin of internal sediments in Jurassic limestones of Burgundy (France) and Fnoud (Algeria). Sedimentology, 30:273-283.

Barber, P. M., 1988. The Exmouth Plateau deep water frontier: a case history. In Purcell, P. G., and Purcell, R. R. (Eds.), The North West Shelf Australia. Proc. Pet. Expl. Soc. Aust. Symp., 173-187.

Bint, A. N., 1988. Gas fields of the Browse Basin. In Purcell, P. G., and Purcell, R. R. (Eds.), The North West Shelf Australia, Proc. Pet. Expl. Soc. Aust. Symp., 413-418.

Bint, A. N., and Helby, R., 1988. Upper Triassic palynofacies and environmental interpretations for the Rankin Trend, northern Carnavon Basin. In Purcell, P. G., and Purcell, R. R. (Eds.), The North West Shelf Australia. Proc. Pet. Expl. Soc. Aust. Symp., 591-598.

Boote, D. R., and Kirk, R. B., 1989. Depositional wedge cycles on evolving plate margin, western and northwestern Australia. $A A P G$ Bull., 73:216-243.

Cantaluppi, G., and Lualdi, A., 1983. L'Hettangiano e suo passagio al Sinemuriano al Pizzo Ceresa (Prepiemontese Ligure; Unità di Arnasco-Castelbianco). Atti Ist. Geol. Univ. di Pavia, 30:215-220.

Cloetingh, S., 1986. Intraplate stresses: a new tectonic mechanism for regional sealevel variations. Geology, 14:617-621.

Curnelle, R., and Cabanis, B., 1989. Relations entre le magmatisme "triasique" et le volcanisma infra-liasique des Pyrénées et de l'Aquitaine; Apports de la géochimie des éléments en traces. Bull. Cent. Rech. Explor.-Prod. Elf-Aquitaine, 13:347-375.

Di Stefano, P., and Senowbari-Daryan, B., 1985. Upper Triassic Dasycladales (Green Algae) from the Palermo Mountains (Sicily, Italy). Geol. Rom., 24:189-220.

Dumont, T., 1988. Late Triassic-early Jurassic evolution of the western Alps and of their European foreland; initiation of the Tethyan rifting. Bull. Soc. Geol. Fr., 4:601-612.

Dumont, T., and Grand, T., 1987. Caractères communs entre l'évolution précoce d'une portion de marge passive fossile (marge européenne de la Téthys Ligure, Alpes Occidentales) et celle du rift de Suez. C. R. Acad. Sci. Paris, 305:1369-1373.

Exon, N. F., von Rad, U., and von Stackelberg, U., 1982. The geological development of the passive margins of the Exmouth Plateau off northwest Australia. Mar. Geol., 47:131-152.
Faure, J. L., and Megard-Galli, J., 1988. L'évolution Jurassique en Briançonnais: sédimentation continentale et fracturation distensive. Bull. Soc. Geol. Fr., 4:681-692.

Flügel, E, 1981. Paleoecology and facies of Upper Triassic reefs in the northern Calcareous Alps. In Toomey, D. F. (Ed.), European Fossil Reef Models, Spec. Publ. Soc. Econ. Paleontol. Mineral., 30: 291-360.

Gildner, R. F., and Cisne, J. L., 1989. Quantitative modeling of carbonate stratigraphy and water depth history using depth-dependant sediment accumulation function. In Cross, T. A. (Ed.), Quantitative Dynamic Stratigraphy: Englewood Cliffs, NJ (Prentice Hall), 417-432.

Gradstein, F., Ludden, J., and Leg 123 Shipboard Scientific Party, 1989. The birth of the Indian Ocean. Nature, 337:506-507.

Grand, T., 1988. Mesozoic extensional inherited structures on the European margin of the Ligurian Tethys. The example of the Bourg d'Oisans half graben, western Alps. Bull. Soc. Geol. Fr., $4: 613-622$.

Haq, B. U., Hardenbol, J., and Vail, P. R., 1987. Chronology of fluctuating sea levels since the Triassic. Science, 235:1156-1167.

Klitgord, K. D., Hutchinson, D. R., and Schouten, H., 1988. U.S, Atlantic continental margin: structural and tectonic framework. In Sheridan, R. E., and Grow, J. A. (Eds.), The Atlantic Continental Margin, U.S. Geol. Soc. Am., Geology of North America, I-2:1953.

Lago, M., 1984. Las espilitas del area del Moncayo (Zaragoza-Soria): caracteres geologicos y petrologicos. Congr. Espanol. Geol., 2:161-176.

Laurent, J. C., in press. Evolution tholéiitique du volcanisme triasique du Massif du Haut-Dauphiné (Ecrins-Pelvoux), C. R. Acad. Sci. Paris.

Lemoine, M., Bas, T., Arnaud-Vanneau, A., Arnaud, H., Dumont, T., Gidon, M., Bourbon, M., de Graciansky, P. C., Rudckiewicz, J. L., Mégard-Galli, J., and Tricart, P., 1986. The continental margin of the Mesozoic Tethys in the western Alps. Mar. Pet. Geol., 3:179-200.

Lualdi, A., 1983. Ricerche stratigraphico-sedimentologiche nel Prepiemontese Ligure: II-II Trias dell'unità di Arnasco-Castelbianco. Atti Ist. Geol. Univ. Pavia, 30:197-214.

Manspeizer, W., 1988. Triassic-Jurassic rifting and opening of the Atlantic: an overview. In Manspeizer, W. (Ed.), Triassic-Jurassic Rifting: Continental Breakup and the Origin of the Atlantic Ocean and Passive Margins: New York (Elsevier), 41-79.

Marcoux, J., and Baumgartner, P. O., in press. Comparison of Mesozoic radiolarites from NeoTethys and the eastern Indian Ocean. In Gradstein, F. M., Ludden, J. N., et al., Proc. ODP, Sci. Results, 123: College Station, TX (Ocean Drilling Program).

Massetti, D., Stefani, M., and Burchell, M., 1989. Asymetric cycles in the Rhaetic facies of Southern Alps: platform-basin interactions governed by eustatic and climatic oscillations. Riv. Ital. Paleontol. Strat., 94:401-424.

Megard-Galli, J., and Baud, A., 1977. Le Trias moyen et supérieur des Alpes nord-occidentales: données nouvelles et corrélations stratigraphiques. Bull. Bur. Rech. Geol. Min., 4:233-250.

Megard-Galli, J., and Faure, J. L., 1988. Tectonique distensive et sédimentation au Ladinien supérieur-Carnien dans la zone brianconnaise. Bull. Soc. Geol. Fr., 4:705-716.

Mettraux, M., and Mohr, B., 1989. Stratigraphy of the Triassic/ Jurassic boundary in the "Préalpes Médianes" nappe: facies and palynology. Eclogae Geol. Helv., 82:743-763.

Middleton, M. F., 1988. Seismic atlas of the North West Shelf. In Purcell, P. G., and Purcell, R. R. (Eds.), The North West Shelf Australia. Proc. Pet. Expl. Soc. Aust. Symp., 457-478.

Piller, W., 1981. The Steinplatte reef complex, part of an Upper Triassic carbonate platform near Salzburg, Austria. In Toomey, D. F. (Ed.), European Fossil Reef Models. Spec. Publ. Soc. Econ. Paleontol. Mineral., 30:261-290.

Posamentier, H. W., and Vail, P. R., 1988. Eustatic control on clastic deposition II. Sequence and systems tracts models. In Wilgus, C. K., Hastings, B. S., Kendall, C. G., Posamentier, H. W., Ross, C. A., and Van Wagoner, J. C. (Eds.), Sea-level Changes: An Integrated Approach: Spec. Publ. Soc. Econ. Paleontol. Mineral., 42:125-154. 
Purcell, P. G., and Purcell, R. R., 1988. The Northwest Shelf Australia: an introduction. In Purcell, P. G., and Purcell, R. R. (Eds.), The North West Shelf Australia. Proc. Pet. Expl. Soc. Aust. Symp., 1-17.

Quilty, P. G., in press. Triassic and Jurassic foraminiferal faunas, northern Exmouth Plateau, eastern Indian Ocean. J. Foraminiferal Res.

Roux, M., Bourseau, J. P., Bas, T., Dumont, T., de Graciansky, P. C., Lemoine, M., and Rudckiewicz, J. L., 1988. Bathymetric evolution of the Tethyan margin in the western Alps (data from stalked crinoids) : a reapraisal of eustatism problems during the Jurassic. Bull. Soc. Geol. Fr., 4:633-641.

Sarg, J. F., 1988. Carbonate sequence stratigraphy. In Wilgus, C. K., Hastings, B. S., Kendall, C. G., Posamentier, H. W., Ross, C. A., and Van Wagoner, J. C. (Eds.), Sea Level Changes: An Integrated Approach. Spec. Publ. Soc. Econ. Paleontol. Mineral., 42:155181.

Schott, M., 1983. Sedimentation und diagenese einer absinkenden karbonatplatform: Rhät und Lias des Brünnstein-Auerbach-Gebietes, Bayerische Kalkalpen. Facies, 9:1-60.

Shipboard Scientific Party, 1990. Site 761. In Haq, B. U., von Rad, U., et al., Proc. ODP, Init. Repts., 122: College Station, TX (Ocean Drilling Program), 161-211.

, 1990. Site 764. In Haq, B. U., von Rad, U., et al., Proc. ODP, Init. Repts., 122: College Station, TX (Ocean Drilling Program), 353-384.

Stanton, R. J., Jr., and Flügel, E., 1989. Problems with reef models: the Late Triassic Steinplatte "reef" (Northern Alps, Salzburg/ Tyrol, Austria). Facies, 20:1-138.

Sutter, J. F., 1989. Innovative approaches to the dating of igneous events in the Early Mesozoic basins of the eastern United States. U.S. Geol. Surv. Bull., 1776:194-200.

Thery, J. M., Cros, P., and Bouroullec, J., 1989. Relationship between organic matter and sedimentological conditions in the
Triassic of northern Italy. Bull. Cent. Rech. Explor.-Prod. ElfAquitaine, 13:23-33.

Venkatakrishnan, R., and Lutz, R., 1988. A kinematic model for the evolution of Richmond Triassic basin, Virginia. In Manspeizer, W. (Ed.), Triassic-Jurassic Rifting: Continental Breakup and the Origin of the Atlantic Ocean and Passive Margins: New York (Elsevier), 456-462.

Vincent, P., and Tilbury, L., 1988. Gas and oil fields of the Rankin Trend and northern Barrow-Dampier Sub-basin. In Purcell, P. G., and Purcell, R. R. (Eds.), The North West Shelf Australia, Proc. Pet. Expl. Soc. Aust. Symp., 341-370.

von Rad, U., Haq, B. U., and Leg 122 Shipboard Scientific Party, 1989a. Breakup of Gondwanaland. Nature, 337:209-210.

von Rad, U., Thurow, J., Haq, B. U., Gradstein, F., Ludden, J., et al., 1989b. Triassic to Cenozoic evolution of the N.W. Australian Margin and the birth of the Indian Ocean (Preliminary results of ODP Legs 122 and 123). Geol. Rundsch., 78:1189-1210.

von Rad, U., Schott, M., Exon, N. F., Mutterlose, J., Quilty, P. G., and Thurow, J., in press. Mesozoic sedimentary and volcanic rocks dredged from the northern Exmouth Plateau: petrography and microfacies. BMR J. Aust. Geol. Geophys.

Williamson, P. E., Exon, N. F., Haq, B. U., von Rad, U., O'Connell, S., and Leg 122 Shipboard Scientific Party, 1989. A Northwest Shelf Triassic reef play: results from ODP Leg 122. APEA J., 29:328-344.

Williamson, P. E., and Falvey, D. A., 1988. Preliminary post-cruise report, Rig Seismic research cruises 7 and 8: deep seismic structure of the Exmouth Plateau. BMR Record, 31.

Date of initial receipt: 22 May 1990

Date of acceptance: 15 January 1991

Ms 122B-142 


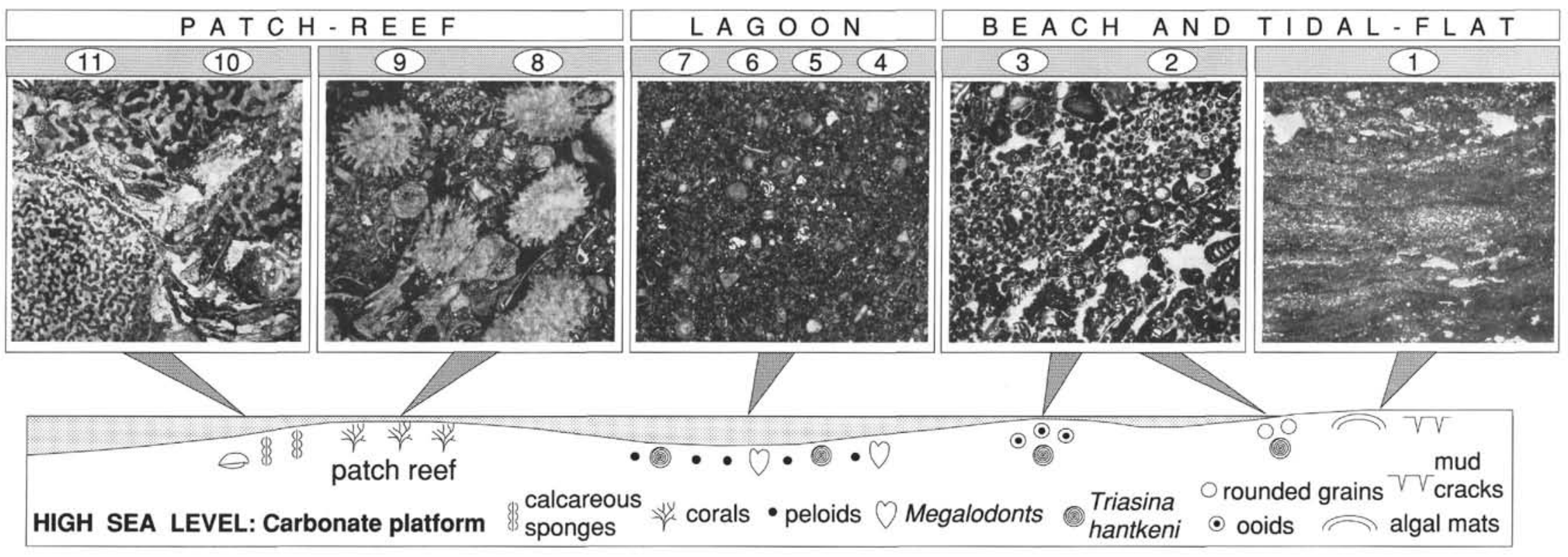

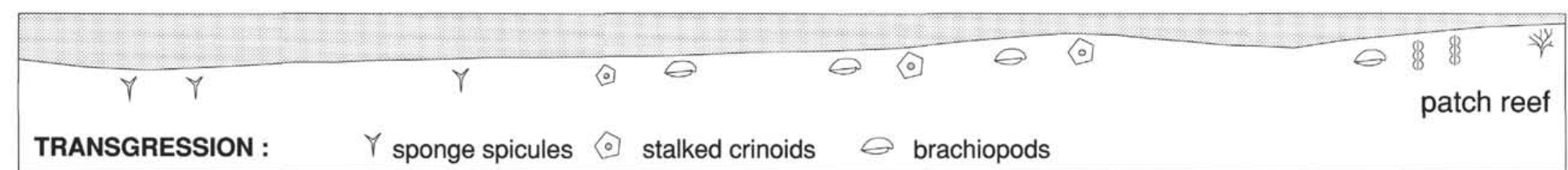

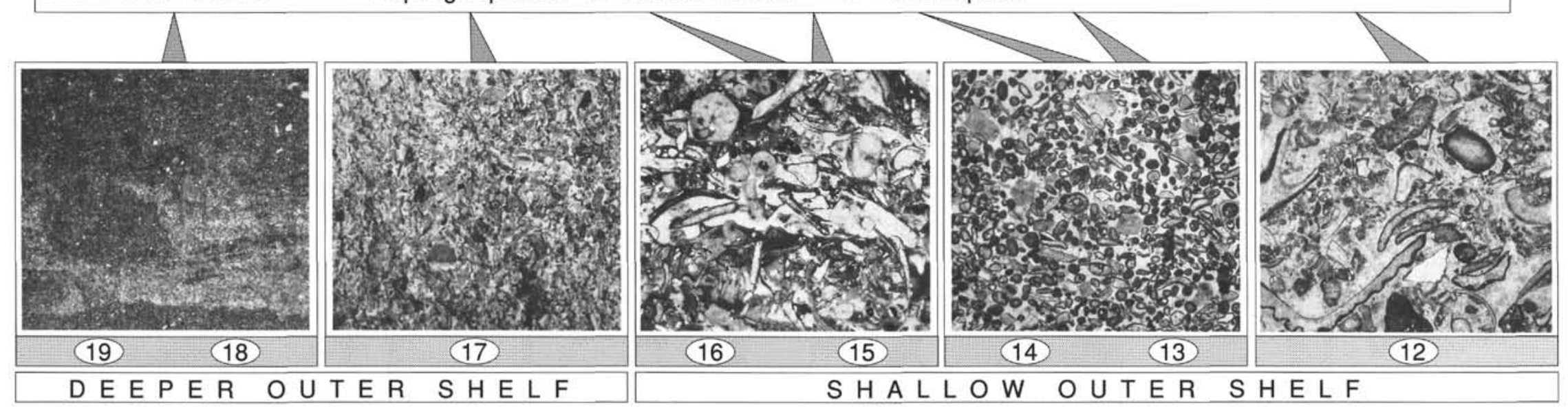

Plate 1. Distribution of some representative Rhaetian microfacies types upon theoretical platform profiles. Two different profiles are used that correspond respectively to transgression to growing of a shallow carbonate platform in the context of relative sea-level stability (a situation mainly observed during deposition of members B and D). 